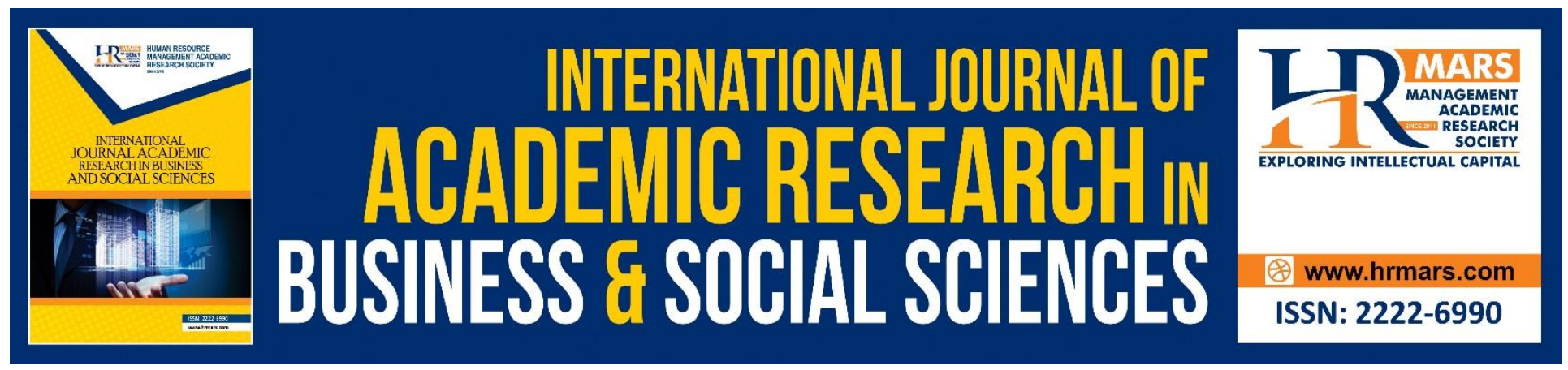

\title{
The Effectiveness of Promotion Strategy Influence Consumer Buying Behavior of Menara Optometry
}

Aimi Nadia Ibrahim @ Zakaria, Nur Ain Mahat, Mardhiah Kamaruddin, Nik Noorhazila Nik Mud, Rozaiyah Abdul Rahman

To Link this Article: http://dx.doi.org/10.6007/IJARBSS/v8-i8/4630

DOI: $10.6007 /$ IJARBSS/v8-i8/4630

Received: 21 June 2018, Revised: 19 July 2018, Accepted: 29 July 2018

Published Online: 12 August 2018

In-Text Citation: (Zakaria, Mahat, Kamaruddin, Mud, \& Rahman, 2018)

To Cite this Article: Zakaria, A. N. I. @, Mahat, N. A., Kamaruddin, M., Mud, N. N. N., \& Rahman, R. A. (2018). The Effectiveness of Promotion Strategy Influence Consumer Buying Behavior of Menara Optometry. International Journal of Academic Research in Business and Social Sciences, 8(8), 756-762.

Copyright: (C) 2018 The Author(s)

Published by Human Resource Management Academic Research Society (www.hrmars.com)

This article is published under the Creative Commons Attribution (CC BY 4.0) license. Anyone may reproduce, distribute, translate and create derivative works of this article (for both commercial and non-commercial purposes), subject to full attribution to the original publication and authors. The full terms of this license may be seen

at: http://creativecommons.org/licences/by/4.0/legalcode

Vol. 8, No. 8, August 2018, Pg. 756 - 762

Full Terms \& Conditions of access and use can be found at http://hrmars.com/index.php/pages/detail/publication-ethics 


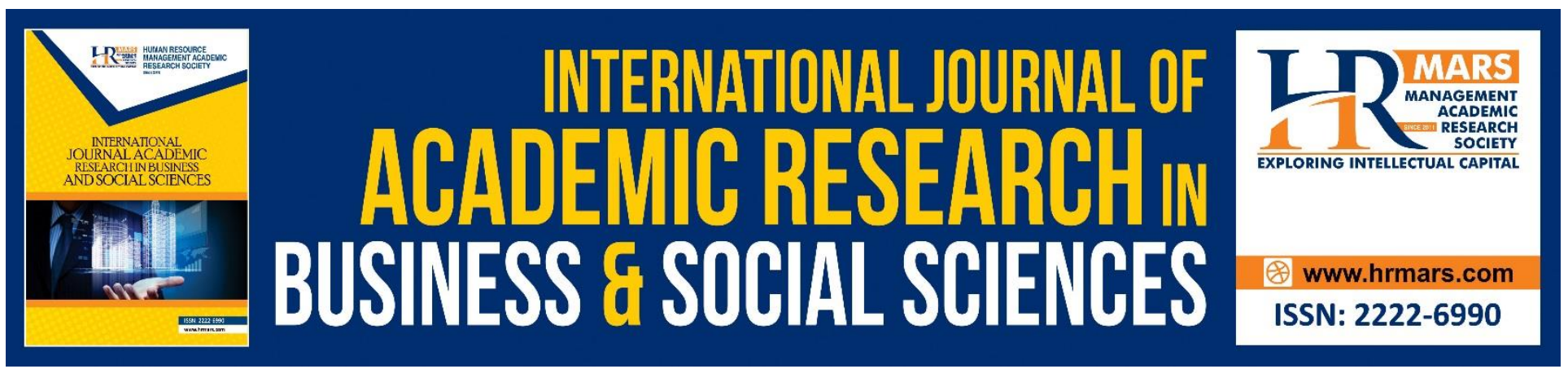

\title{
The Effectiveness of Promotion Strategy Influence Consumer Buying Behavior of Menara Optometry
}

\author{
Aimi Nadia Ibrahim @ Zakaria \\ Universiti Malaysia Kelantan, Malaysia \\ Nur Ain Mahat \\ Universiti Malaysia Kelantan, Malaysia \\ Mardhiah Kamaruddin \\ Universiti Malaysia Kelantan, Malaysia \\ Nik Noorhazila Nik Mud \\ Universiti Malaysia Kelantan, Malaysia \\ Rozaiyah Abdul Rahman \\ Universiti Teknologi Mara Shah Alam, Malaysia
}

\begin{abstract}
This research explore the effectiveness of promotion strategy influencing buying behaviour on consumer of Menara Optometry with the purpose to identify the correlation between the promotion activities issue and buying behaviour in franchising business model. It is suggested that advertising, sales promotion, social media, and corporate social responsibility are the independent variables that influence buying behaviour. By conducting descriptive study, questionnaires were distributed to 200 respondents. An interview with the outlet owner been conducted to gather the information. At the end of the study, we found that corporate social responsibility, social media, advertising such flyer and banner and sales promotion have relationship between consumer buying behaviour on Menara Optometry optical product.
\end{abstract}

\section{Introduction}

It is insufficient for an organization offers item at alluring cost without convey it to customer. To generate sales and profit, they used promotion mix to communicate with consumers. Promotion is the key components of the marketing mix, it involved a two way communications or a deal that take place with the consumer. It is additionally the immediate way an organization tries to reach its target 
market. Promotion is the common approach to raise customer attention to an item or brand, generate sale, and create brand loyalty.

Promotion is the purpose to create a purchasing power by strengthening the communication between consumer and the product offered (Abukawa, Lopes and Reis (1996). According to Walnut , Lazzarini, (2011), the information that been translate will assist consumer to make decision due to the possibility of supporting an existing need. Sauaia; Silva, (2008) has portray limited time instruments have the objective to make extra volume and minimize the expense of offers. As indicated by Czinkota and Ronkainen, (2004), there are five types of promotion mix, which is advertising, sales promotion, public relation, and personal selling. Majority of manufacturer or retailers use promotion to attract the consumer. Company will utilize distinctive sorts of promotional tools and promotional strategies to enable them to better understand the consumer fondness and improve their sales.

A consumer's buying behavior is leverage by cultural, community, individual and psychological factors. Majority of the components are wild and beyond the hands of marketers yet they need to consider while attempting comprehending the unpredictable behavior of the consumers. According to Engel et al. $(1986,5)$ consumer behavior as those individuals will consume directly involved in purchasing, using and disposing of economic goods and services, including the decision process that precede and determine these actions.

Menara Optometry franchise store TTDI Shah Alam owned by Pn Mariaton Binti Rosman, started the business since 2013 till now. The company was registered under name RDS MAJU SDN BHD, with a franchise fee RM 250000 . They currently has 2 female specialists whom provides eyes care services for all ages, professions and interest, thus ensuring the well being of its customers in their daily activities. To ensure Menara Optometry remain competitive, each outlet is extremely equipped with the most recent optometry equipment operated by qualified optometrist registered with the Malaysian Optical Council. Menara Optometry Sdn Bhd formed franchise scheme since 2008. They offer the opportunity for optometrist to join their franchise program. Menara Optometry conducts marketing activities on conventional marketing. They distribute flyers, banner and word of mouth activities. In franchise system, franchisee will follow franchisor activity. However, in Menara Optometry, there several franchise outlets perform promotion activities different with franchise system example TTDI Jaya outlet, Menara Optometry Andalas, Klang, Menara Optometry Wangsa Melawati, and Menara Optometry Prima Saujana. They utilize social media, advertising such as flyer and banner, sales promotion for example in store promotion and corporate social responsibility activities to promote their product.

\section{Overview of Franchising in Malaysia}

Franchising began in the 1850's when Isaac Singer designs the sewing machine. With a specific end goal to appropriate his machines outside of his geological range, furthermore give preparing to clients, Singer started offering licenses to business visionaries in diverse parts of the nation. Ray Kroc in year 1955, assumed control over a little chain of nourishment establishments and incorporated it with today best fast food restaurant chain establishment on the planet, now known as McDonald's. McDonald's as of now has the most establishment units worldwide of any establishment framework.

Franchisor has the total control of the franchisee business, in order to ensure entrepreneur operates the business in accordance. There is typically a much higher probability of progress when an individual opens a franchise compare to traditional family business, since a demonstrated business 
plan and guide is given to the entrepreneur. Their products, services, and business operations are already established.

There are advantage of operating franchise business, some of these advantage are:

i. Company image - The company image and brand consciousness of the organization is as of now settled. Consumers are constantly more open to buying things from a natural name or organization they trusted.

ii. Training - The franchisor will give the full training to the franchisee.

iii. Time management - Franchisee can focus on the business operating, since the franchise company has guide them with the actions plan

Franchising began in Malaysia in the 1930s with the presentation of the introduction of the product distribution franchises establishments such the Singer Sewing Machines, petrol kiosk, for example, Shell and Esso and automobiles via the Wearne Brothers. A \& W was the first fast food franchise that came to Malaysia in the 1960s, KFC in 1973 and McDonalds in 1982. In 1992 the Honorable Dr. Mahathir Mohamad, decided that franchise was to be given special encouragement to create and prosper in Malaysia. According to Malaysian Franchise Association (MFA), Malaysia's franchise industry is expected to contribute RM 25.6 billion to the nation's economy in 2015 as it has contribute 2.5\% of RM 2.4 billion to the country economy in 2013 (Bernama, 2016). There were 726 franchises business that has been registered from different sectors while 58 Malaysian franchise brands had ventured in abroad to 53 countries operating 1922 outlets.

As practiced in other franchise business model, the advertising and promotion strategies activities for Menara Optometry are mainly the responsibilities of the franchisor. This is to ensure uniformity of corporate image and no conflicting information being disseminated to the potential consumers or the public at large. The franchisor of Menara Optometry prefers to use the conventional promotional tool as shown in table 2 . Their rationale is that these mediums are sufficient to create awareness and interest of potential customers to choose Menara Optometry over other optometry houses. 
INTERNATIONAL JOURNAL OF ACADEMIC RESEARCH IN BUSINESS AND SOCIAL SCIENCES Vol. 8, No. 8, August 2018, E-ISSN: 2222-6990 @ 2018 HRMARS

Table 1: Franchisor Marketing Activities

Franchisor's Main Promotion
Tools
Marketing activities
Outdoor advertsing:
1. Flyers
2. Banner
3. Viral marketing (word of
mouth)

Table 2: Franchisee Marketing Activities

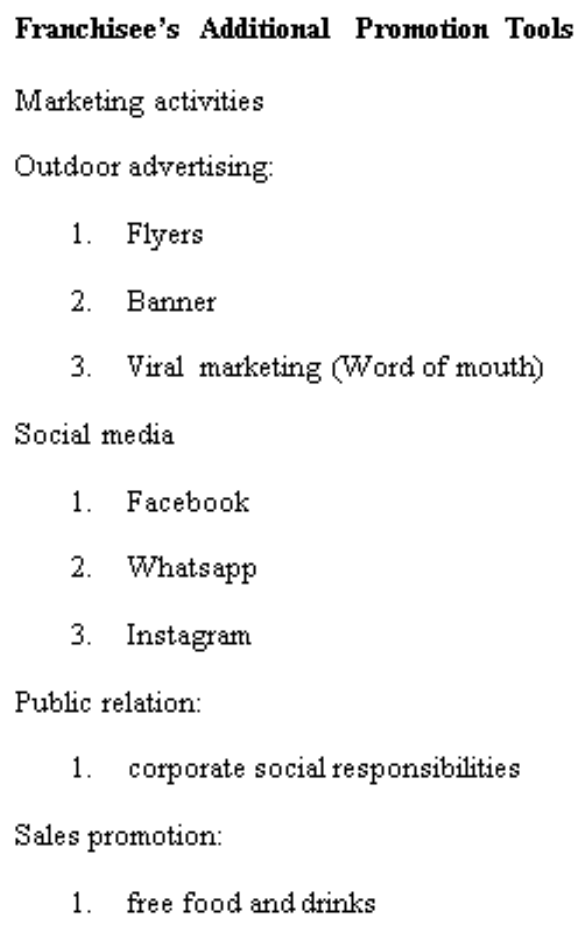

\section{Research Methodology Data Collection}

The researcher had interview franchisees in order to obtain information on the issue of interest. Basically, a structured interview had been conducted when the researcher known what kind of information needed. The question normally related or relevant to the problem addressed. The second data collection method, questionnaires, was one of the efficient data collection mechanisms when the researcher knows exactly what was required and how to measure the variables of interest. Here, the researcher had used personally administered questionnaires where to approach consumers directly. The researcher decided to collect data from the consumers Menara Optometry, approximately 200 individuals, and analyze the data. These questionnaires were distributed to three areas which are TTDI Jaya franchise outlet, Menara Optometry Wangsa Melawati, and Menara Optometry Mydin Subang Jaya. 
INTERNATIONAL JOURNAL OF ACADEMIC RESEARCH IN BUSINESS AND SOCIAL SCIENCES

Vol. 8, No. 8, August 2018, E-ISSN: 2222-6990 @ 2018 HRMARS

\section{Findings}

\section{Correlation Analysis}

Table 3: Pearson correlation analysis Correlation Coefficient

\begin{tabular}{lllllll}
\hline & Variable & $\mathbf{1}$ & $\mathbf{2}$ & $\mathbf{3}$ & $\mathbf{4}$ & $\mathbf{5}$ \\
\hline 1. & Buying Behavior & 1 & 0.42 & 0.45 & 0.43 & 0.43 \\
\hline 2. & Advertising & 0.42 & 1 & 0.49 & 0.25 & 0.43 \\
\hline 3. & $\begin{array}{l}\text { Corporate Social } \\
\text { Responsibility }\end{array}$ & 0.45 & 0.49 & 1 & 0.54 & 0.53 \\
\hline 4. $\quad$ Social Media & 0.43 & 0.25 & 0.54 & 1 & 0.49 \\
\hline 5. & Sales Promotion & 0.43 & 0.43 & 0.53 & 0.49 & 1 \\
\hline ** Correlation is significant at the 0.01 level (2-tailed). & & \\
\hline
\end{tabular}

Table 3 show the correlation between the independent variables and dependent variable. First, the results showed that there was a significant relationship between advertising and buying behavior $(p<0.001, r=0.42)$ indicating moderate to good correlation between the variables since $p<0.001$. According to Clark et, al. (2009), advertising is the method to influence customer selection and it is important to realizable by practitioners and researcher. Bravo, et al. (1995) stated that advertising enhance affiliation of consumer via text, spoken, and visual interpretation on media. Second, there was significant relationship between corporate social responsibility and consumer buying behavior in franchise business model $(p<0.001, r=0.45)$ indicating moderate to good correlation between the variables since $p<0.001$. This result support by Foster et, al (2009), CSR help enhancing brand or corporate image and reputation. CSR helps to improve access capital to organization and it strengthen the arguments for CSR programmes are driving companies increasingly towards the adoption of socially and environmentally responsible strategies (Moser and Miller, 2001). Third, there was a significant relationship between social media and buying behavior $(p<0.001$, $r=0.43$ ) indicating moderate to good correlation between the variable. According to Hanna, Rohn and Crittenden, (2011), the unique aspects and the popularity of social media have revolutionized marketing practices such as promotion and advertising. Social media help companies to engage with the potential consumer and increased sense of intimacy with consumer and build the relationship with them. Example, Tesco is using Youtube to promote their online shopping service and promoting mobile apps online shopping. Sales promotion has significant relationship with buying behavior $(p<0.001, r=0.43)$ indicating moderate to good relationship between variable since $p<0.001$. According to William \& Ferrell (1987), sales promotion is an activity that acts as a direct motivation, offering added value or incentive for a product to resellers, salespersons or customers. Based on US survey of promotional practice showed that, price coupons were the favorite promotional tool. 
INTERNATIONAL JOURNAL OF ACADEMIC RESEARCH IN BUSINESS AND SOCIAL SCIENCES Vol. 8, No. 8, August 2018, E-ISSN: 2222-6990 @ 2018 HRMARS

\section{Conclusion and Recommendations}

In the nut shell, the overall study has been identified and the finding of the data has discussed. After running the Pearson Correlation Analysis, all the variables advertising, corporate social responsibility, social media and sales promotion have shown a significant relationship with consumer buying behavior of Menara Optometry product. From the result finding, it shown Corporate Social Responsibility has great impact influencing on consumer buying pattern Customers are more aware and sensitive with the way of organization behave and it influence consumer buying pattern. According to Tay (2005), Corporate social responsibility has major impact in consumer decision making because the CSR activities had portray the organization good image in engage with customers. This study also recommend that Menara Optometry should formulate effective and comprehensive promotion strategies that seek to build brand awareness, customer loyalty, inducing purchase and increase sales.

\section{Corresponding Author}

Aimi Nadia Binti Ibrahim @ Zakaria, Universiti Malaysia Kelantan, Malaysia

Email: aiminadia.i@umk.edu.my, Universiti Malaysia Kelantan, Karung Berkunci 36, Taman

Bendahara, 16100 Kota Bharu, Kelantan.

\section{References}

Abd R. Rahizah, Jalaludin. Farah Waheeda, \& Tajuddin. Kasmah. (2011). The Importance of Corporate Social Responsibility On Consumer Behavior In Malaysia. Journal Of Management Asian Academy, 1 (16) 119-139.

Adebisi, S.A., \& Babatunde, B. O. (2011). Strategic Influence Promotion Mix On Organization Sale Turnover In The Face Of Strong Competitors. Journal Of Business Intelligent.

Bernama. (2016, November 16). Malaysian franchise industry flourishing. Astro AWANI.

Kwok, S., \& Uncles. M. (2005). Sales promotion effectiveness: the impact of consumer differences at ethnic-group level. Journal of Product \& Brand Management, 3 (14), 170-186.

Marcelo R.V., \& Paolo C. (2011). The influence of belonging to virtual brand communities on consumers' affective commitment, satisfaction and word-of-mouth advertising, Online Information Review, 4(35), 517 - 542.

Peattie, K., \& Peattie, S. (1995). Sales promotion-a missed opportunity for services marketers?. International Journal of Service Industry Management, 1 (6), 22-39.

Retrieved from http://english.astroawani.com/business-news/malaysian-franchise-industryflourishing-122724 